DOI: https://dx.doi.org/10.33289/IJRPC.10.1.2020.10(28)

\title{
ANALYTICAL METHOD DEVELOPMENT AND VALIDATION FOR THE SIMULTANEOUS ESTIMATION OF DARUNAVIR AND COBICISTAT BY RP- HPLC METHOD
}

\author{
Prem Kumar Bichala , Rakesh sharma, Naveen Kumar, \\ Ali Lawal, Auwalu Ibrahim and Mohammed Umar \\ School of Pharmaceutical Sciences, Pratap University, \\ Sunderpura - 303 104, Jaipur, Rajasthan, India
}

\begin{abstract}
A new method was established for simultaneous estimation of Cobicistat and Darunavir by RPHPLC method. The chromatographic conditions were successfully developed for the separation of Cobicistat and Darunavir by using Xterra C18 $5 \mu \mathrm{m}(4.6 * 250 \mathrm{~mm})$ column, flow rate was $1 \mathrm{ml} / \mathrm{min}$, mobile phase ratio was Phosphate buffer $(0.05 \mathrm{M}) \mathrm{pH} 4.6: \mathrm{ACN} \quad(55: 45 \% \mathrm{v} / \mathrm{v}) \quad$ (pH was adjusted with orthophosphoric acid), detection wave length was $255 \mathrm{~nm}$. The instrument used was WATERS HPLC Auto Sampler, Separation module 2695, PDA Detector 996, Empowersoftware version-2. The analytical method was validated according to ICH guidelines (ICH, Q2 (R1)). The linearity study for Cobicistat and Darunavir was found in concentration range of $1 \mu \mathrm{g}-5 \mu \mathrm{g}$ and $100 \mu \mathrm{g}-500 \mu \mathrm{g}$ and correlation coefficient (r2) was found to be 0.999 and 0.999 , $\%$ mean recovery was found to be $100 \%$ and $100.5 \%$, \%RSD for repeatability was 0.2 and $0.4, \%$ RSD for intermediate precision was 0.5 and 0.1 respectively.
\end{abstract}

Keywords: Cobicistat, Darunavir, RP-HPLC, Phosphate buffer and ACN.

\section{INTRODUCTION COBICISTAT}

Cobicistat is a licensed drug for use in the treatment of infection with the human immunodeficiency virus (HIV). cobicistat is of interest for its ability to inhibit liver enzymes that metabolize other medications used to treat HIV. Cobicistat is a potent inhibitor of cytochrome P450 3A enzymes, including the important CYP3A4 subtype. It also inhibits intestinal transport proteins, increasing the overall absorption of several HIV medications,including gatazanavir, darunavir and tenofovir alafenamide fumarate. ${ }^{1}$

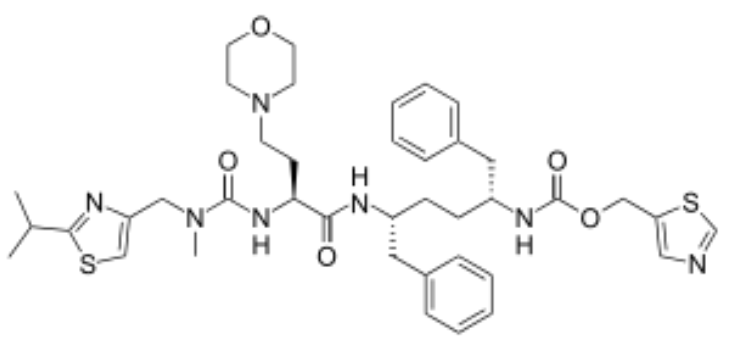

IUPAC Name

Thiazol-5-ylmethyl N-[1-benzyl-4-[[2-[[(2isopropylthiazol-4-yl)methyl-methylcarbamoyl]amino]-4-morpholinobutanoyl]amino]-5-phenyl pentyl]carbamate Chemical formula : $\mathrm{C}_{40} \mathrm{H}_{53} \mathrm{~N}_{7} \mathrm{O}_{5} \mathrm{~S}_{2}$. 
Darunavir (brand name Prezista, formerly known as TMC114) is a protease inhibitor drug used to treat HIV infection. Prezista is an OARAC recommended treatment option for treatment-naïve and treatment-experienced adults and adolescents. Developed by pharmaceutical company Tibotec. Darunavir is a second-generation protease inhibitor (PIs), designed specifically to overcome problems with the older agents in this class, such as indinavir. ${ }^{3}$

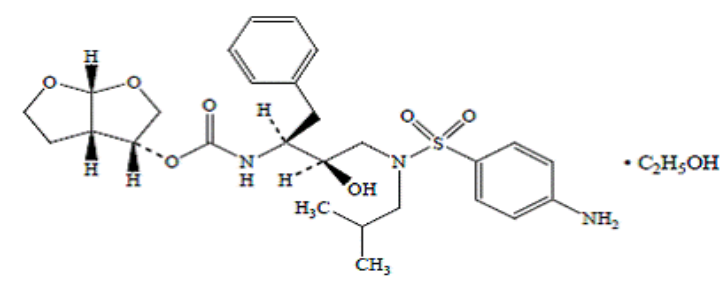

IUPAC Name

[(1S,2R)-3-[[(4aminophenyl)sulfonyl] (2methylpropyl)amino]-2-hydroxy-1-

(phenylmethyl)propyl]-carbamic acid (3R,3aS,6aR)hexahydrofuro[2,3-b]furan-3-yl ester monoethanolate6-

\section{Chemical formula}

$\mathrm{C}_{27} \mathrm{H}_{37} \mathrm{~N}_{3} \mathrm{O}_{7} \mathrm{~S} \cdot \mathrm{C}_{2} \mathrm{H}_{5} \mathrm{OH}$

\section{MATERIALS AND METHODS}

i. Instrument

HPLC instrument used was of WATERS HPLC 2965 SYSTEM with Auto Injector and PDA Detector. Software used is Empower

\section{ii. Chemicals and Solvents}

All the chemicals and solvents used were of analytical grade. Milli $Q$ water was used throughout the experiment.

\section{iii. Solutions}

\section{Preparation of Phosphate buffer}

(PH: 4.6)

Weighed 6.8 grams of $\mathrm{KH} 2 \mathrm{PO} 4$ was taken into a $1000 \mathrm{ml}$ beaker, dissolved and diluted to $1000 \mathrm{ml}$ with HPLC water, adjusted the $\mathrm{pH}$ to 4.6 with ortho phosphoric acid.

\section{Preparation of mobile phase}

A mixture of $\mathrm{pH} 4.6$ Phosphate buffer $300 \mathrm{~mL}$ $(30 \%), 700 \mathrm{~mL}$ of $\mathrm{ACN}(70 \%)$ are taken and degassed in ultrasonic water bath for 5 minutes. Then this solution is filtered through $0.45 \mu$ filter under vacuum filtration.

\section{Diluent Preparation}

Mobile phase is used as Diluent.
Preparation of the individual Cobicistat standard preparation

$10 \mathrm{mg}$ of Cobicistat working standard was accurately weighed and transferred into a $10 \mathrm{ml}$ clean dry volumetric flask and about $2 \mathrm{ml}$ of DMF is added. Then it is sonicated to dissolve it completely and made volume upto the mark with the diluent (Stock solution). Further $10 \mathrm{ml}$ from the above stock solution is pipette into a $100 \mathrm{ml}$ volumetric flask and was diluted upto the mark with diluent.

\section{Preparation of the individual Darunavir standard preparation}

$10 \mathrm{mg}$ of Darunavir working standard was accurately weighed and transferred into a $10 \mathrm{ml}$ clean dry volumetric flask and about $2 \mathrm{ml}$ of DMF is added. Then it is sonicated to dissolve it completely and made volume upto the mark with the diluant (Stock solution). Further $10 \mathrm{ml}$ from the above stock solution is pipette into a $100 \mathrm{ml}$ volumetric flask and was diluted upto the mark with diluent.

\section{Preparation of Sample Solution (Tablet)}

Accurately 10 tablets are weighed and crushed in mortar and pestle and weight equivalent to $10 \mathrm{mg}$ of Darunavir and Cobicistat (marketed formulation) sample into a $10 \mathrm{~mL}$ clean dry volumetric flask and about $7 \mathrm{~mL}$ of Diluents is added and sonicated to dissolve it completely and made volume upto the mark with the same solvent. (Stock solution) Further $3 \mathrm{ml}$ of above stock solution was pipetted into a $10 \mathrm{ml}$ volumetric flask and diluted upto the mark with diluent.

\section{Chromatographic Conditions}

$\begin{array}{ll}\text { Column } & : \text { Inertsil C18 } 5 \mu \mathrm{m} \\ \left(4.6^{\star} 250 \mathrm{~mm}\right) & \\ \text { Mobile phase ratio } & : \text { Phosphate buffer } \\ \text { (0.05M) pH 4.6: ACN }(30: 70 \% \mathrm{v} / \mathrm{v}) & \\ \text { Detection wavelength } & : 255 \mathrm{~nm} \\ \text { Flow rate } & : 1 \mathrm{ml} / \mathrm{min} \\ \text { Injection volume } & : 20 \mu \mathrm{L} \\ \text { Column temperature } & : \text { Ambient } \\ \text { Rt } & : 2.399,3.907\end{array}$

\section{RESULTS AND DISCUSSION Method Development}

The chromatographic method development for the simultaneous estimation of Cobicistat and Darunavir were optimized by several trials for various parameters as different column, flow rate and mobile phase, finally the optimized chromatographic method was selected for the separation and quantification of Cobicistat and Darunavir in API and pharmaceutical dosage form by RP-HPLC method. $^{9}$ 


\section{Optimized Chromatographic Conditions}

Column : Inertsil C18 $5 \mu \mathrm{m}\left(4.6^{\star} 250 \mathrm{~mm}\right)$

Mobile phase ratio : Phosphate

buffer (0.05M) pH 4.6: ACN $(30: 70 \% \mathrm{v} / \mathrm{v})$

Detection wavelength : $\quad 255 \mathrm{~nm}$

Flow rate : $1 \mathrm{ml} / \mathrm{min}$

Injection volume $\quad: \quad 20 \mu l$

Column temperature : $\quad$ Ambient

$\begin{array}{lll}\text { Rt } & \text { : } \quad 2.399,3.907\end{array}$

Fig 1: The chromatogram is perfect with clear separation of components. The peak symmetry and system suitability parameters are within the limits. Hence this method is chosen as optimized one.

\section{Method Validation ${ }^{8,10}$}

Linearity

The linearity study was performed for the concentration of $100 \mathrm{ppm}$ to $500 \mathrm{ppm}$ and1ppm to $5 \mathrm{ppm}$ level. Each level was injected into chromatographic system. The area of each level was used for calculation of correlation coefficient. Results were shown in Table 1 and Linearity plot was shown in Fig 2 \& Fig 3

\section{Accuracy}

The accuracy study was performed for $50 \%, 100 \%$ and $150 \%$ for Cobicistat and Darunavir. Each level was injected in triplicate into chromatographic system. The area of each level was used for calculation of $\%$ recovery and Results were shown in Table 2 and chromatograms were shown in Fig 4-6.

\section{Precision}

The precision study was performed for five injections of Cobicistat and Darunavir. Each standard injection was injected in to chromatographic system. The area of each Standard injection was used for calculation of $\%$ RSD. Results were shown in Table 3 and chromatogram was shown in fig 7.

\section{Limit of Detection and Limit of Quantification \\ LOD and LOQ were determined by using the formula based on the standard deviation of the response and the slope. LOD and LOQ were calculated by using equations,}

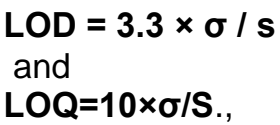

The results were presented in Table 5 . Where $\sigma=$ Standard deviation of the response $\mathrm{S}=$ Slope of the calibration curve

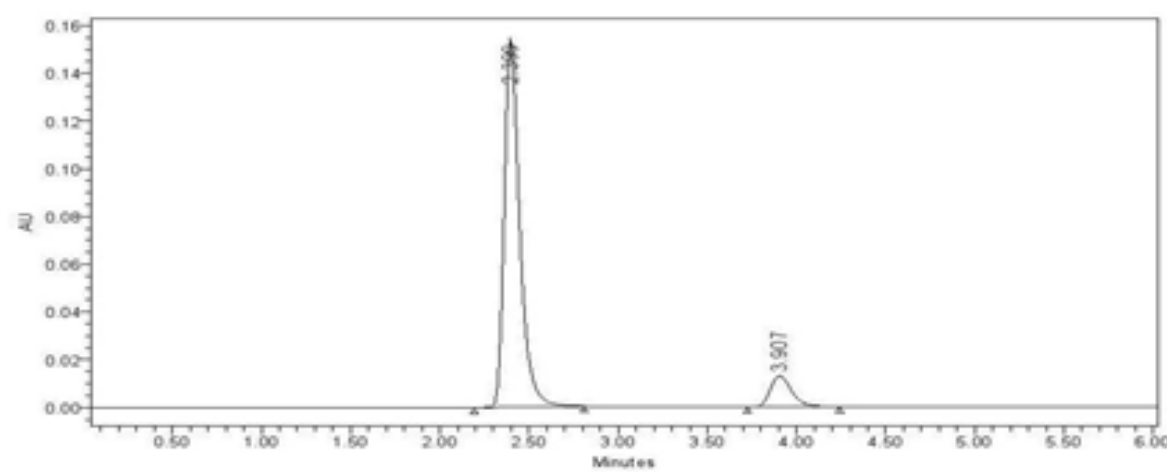

Fig. 1: Optimized chromatogram

Table 1: Linearity results of Cobicistat and Darunavir

\begin{tabular}{|c|l|l|l|l|r|}
\hline & SampleName & \multicolumn{1}{|c|}{ Name } & \multicolumn{1}{|c|}{ RT } & \multicolumn{1}{|c|}{ Area } & $\begin{array}{c}\text { Height } \\
\text { (HV) }\end{array}$ \\
\hline 1 & Linearty 1 & Cobicistat & 2.309 & 1810101 & 145957 \\
\hline 2 & Linearty 1 & Darunavir & 4.307 & 1164173 & 75128 \\
\hline 3 & Linearty 2 & Coblolstat & 2.322 & 2044287 & 176935 \\
\hline 4 & Linearty 2 & Darunavir & 4.317 & 1342535 & 87703 \\
\hline 5 & Linearty 3 & Coblcistat & 2.324 & 2367133 & 206622 \\
\hline 6 & Linearty 3 & Darunavir & 4.323 & 1555931 & 101999 \\
\hline 7 & Linearty 4 & Cobicistat & 2.336 & 2602279 & 228576 \\
\hline 8 & Linearty 4 & Darunavir & 4.340 & 1777973 & 117084 \\
\hline 9 & Linearty 5 & Cobicistat & 2.345 & 2869778 & 259346 \\
\hline 10 & Linearty 5 & Darunavir & 4.340 & 1942319 & 129409 \\
\hline
\end{tabular}




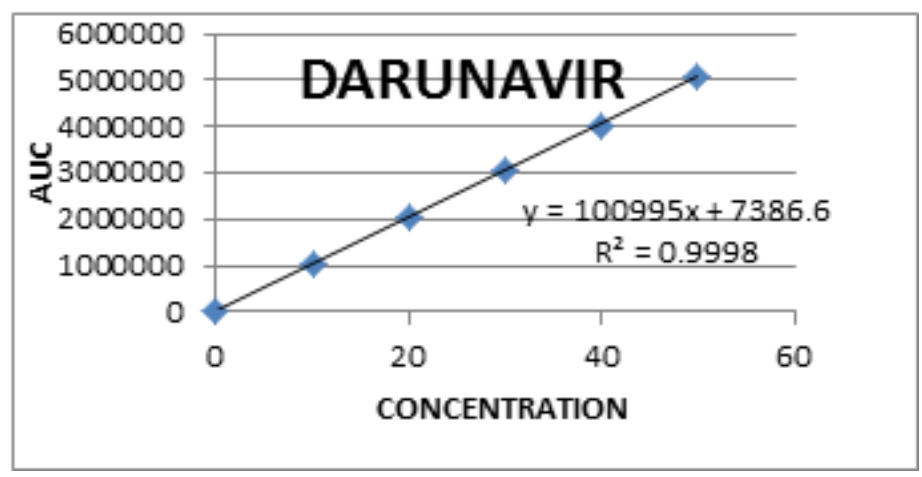

Fig. 2: Calibration curve of Darunavir

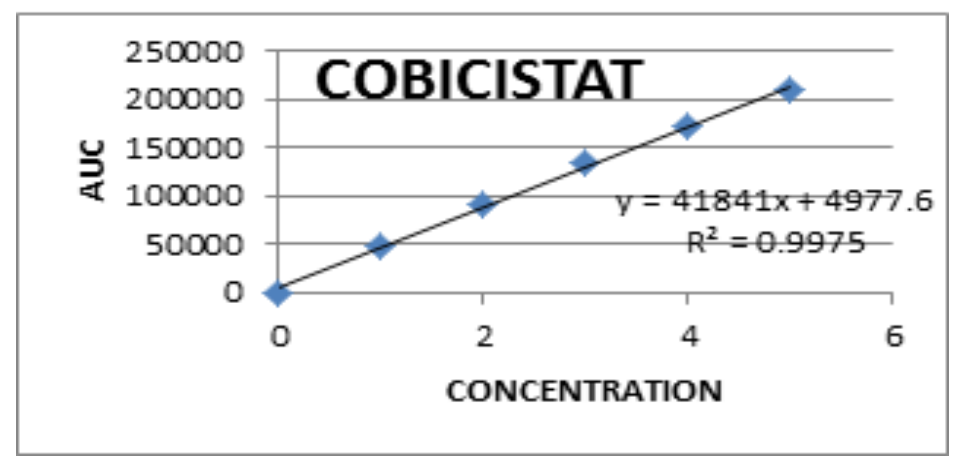

Fig. 3: Calibration curve of Cobicistat

Table 2: Accuracy data of Cobicistat and Darunavir

\begin{tabular}{|c|c|c|c|c|c|c|}
\hline \multirow[b]{2}{*}{$\begin{array}{c}\text { \%Concentration } \\
\text { (at specification } \\
\text { Level) }\end{array}$} & \multicolumn{3}{|c|}{ Cobicistat } & \multicolumn{3}{|c|}{ Darunavir } \\
\hline & $\begin{array}{c}\text { Amount } \\
\text { Added } \\
\text { (ppm) }\end{array}$ & $\begin{array}{l}\text { Amount } \\
\text { Found } \\
\text { (ppm) }\end{array}$ & $\begin{array}{c}\% \\
\text { Recovery }\end{array}$ & $\begin{array}{l}\text { Amount } \\
\text { Added } \\
(\mathrm{ppm})\end{array}$ & $\begin{array}{l}\text { Amount } \\
\text { Found } \\
\text { (ppm) }\end{array}$ & $\%$ Recovery \\
\hline 50 & 5 & 5.0 & $101.3 \%$ & 5 & 5.10 & $101.8 \%$ \\
\hline 100 & 10 & 9.94 & $99.4 \%$ & 10 & 9.99 & $99.9 \%$ \\
\hline 150 & 15 & 14.8 & $99.2 \%$ & 15 & 14.9 & $99.1 \%$ \\
\hline $\begin{array}{c}\text { Mean \% } \\
\text { Recovery }\end{array}$ & & & $100 \%$ & & & $100.5 \%$ \\
\hline
\end{tabular}

\section{Acceptance Criteria}

The $\%$ Recovery for each level should be between 98.0 to $102.0 \%$.

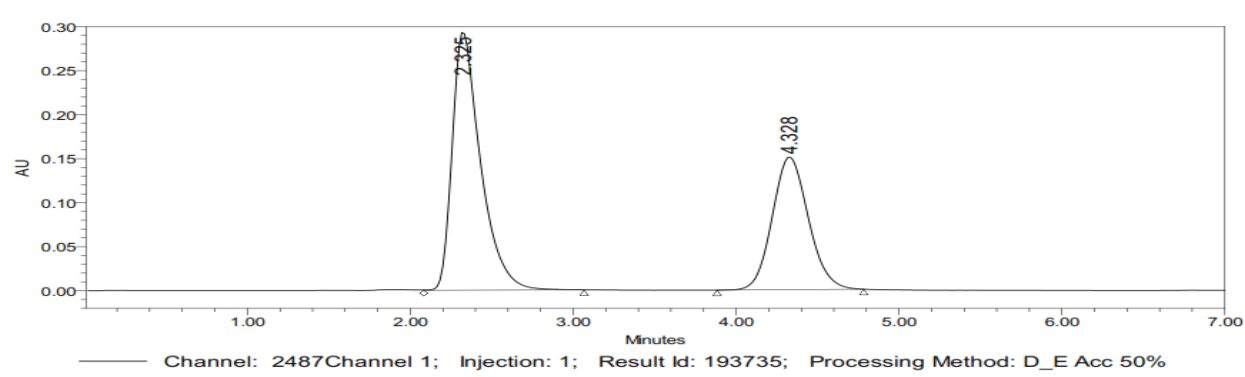

Fig. 4: Accuracy 50\% Chromatogram 


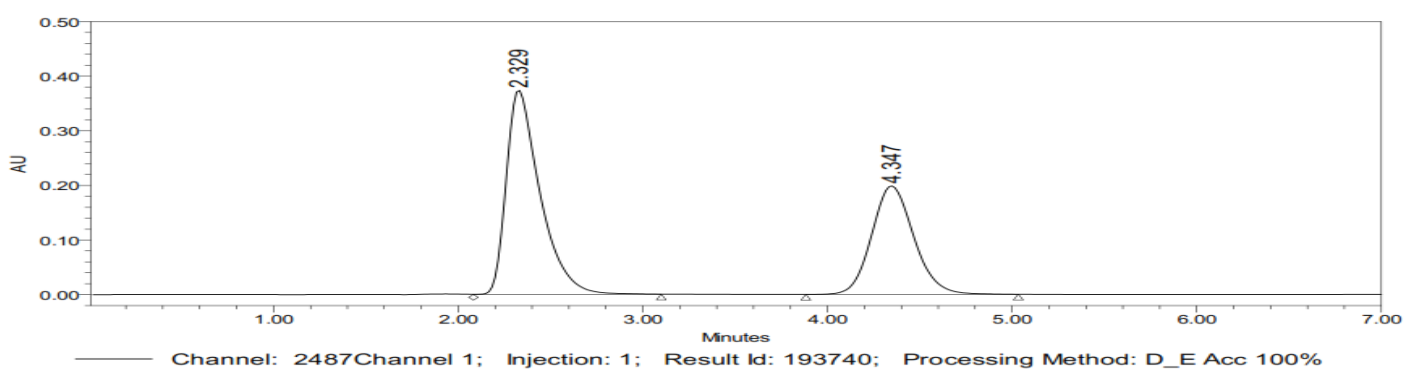

Fig. 5: Accuracy 100\% Chromatogram

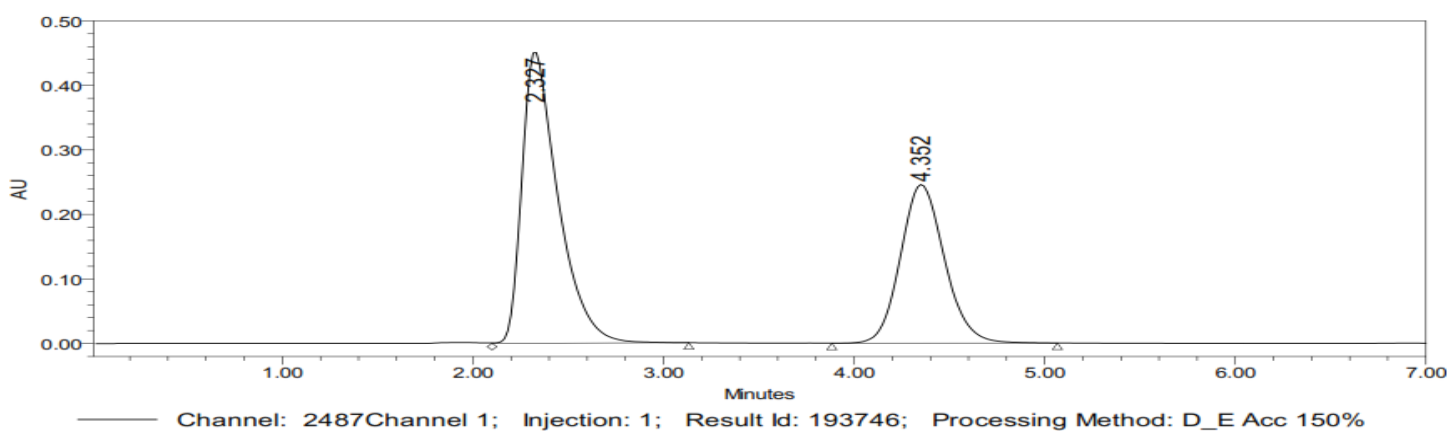

Fig. 6: Accuracy $150 \%$ Chromatogram

Table 3: Precession results of Cobicistat\& Darunavir

\begin{tabular}{|c|c|c|c|c|}
\hline \multirow{2}{*}{$\begin{array}{l}\text { Injection } \\
\text { No. }\end{array}$} & \multicolumn{2}{|c|}{ Cobicistat } & \multicolumn{2}{|c|}{ Darunavir } \\
\hline & $\begin{array}{l}\text { Retention } \\
\text { time (min) }\end{array}$ & Peak area & $\begin{array}{l}\text { Retention time } \\
\text { (min) }\end{array}$ & Peak area \\
\hline 1 & 2.321 & 2235319 & 4.304 & 1501417 \\
\hline 2 & 2.317 & 2240678 & 4.300 & 1486940 \\
\hline 3 & 2.323 & 2249490 & 4.308 & 1490656 \\
\hline 4 & 2.322 & 2245822 & 4.310 & 1487329 \\
\hline 5 & 2.324 & 2251694 & 4.314 & 1490384 \\
\hline Mean & & 2244601 & & 1491345 \\
\hline SD & & 6656.8 & & 5881.4 \\
\hline \%RSD & & 0.3 & & 0.39 \\
\hline
\end{tabular}

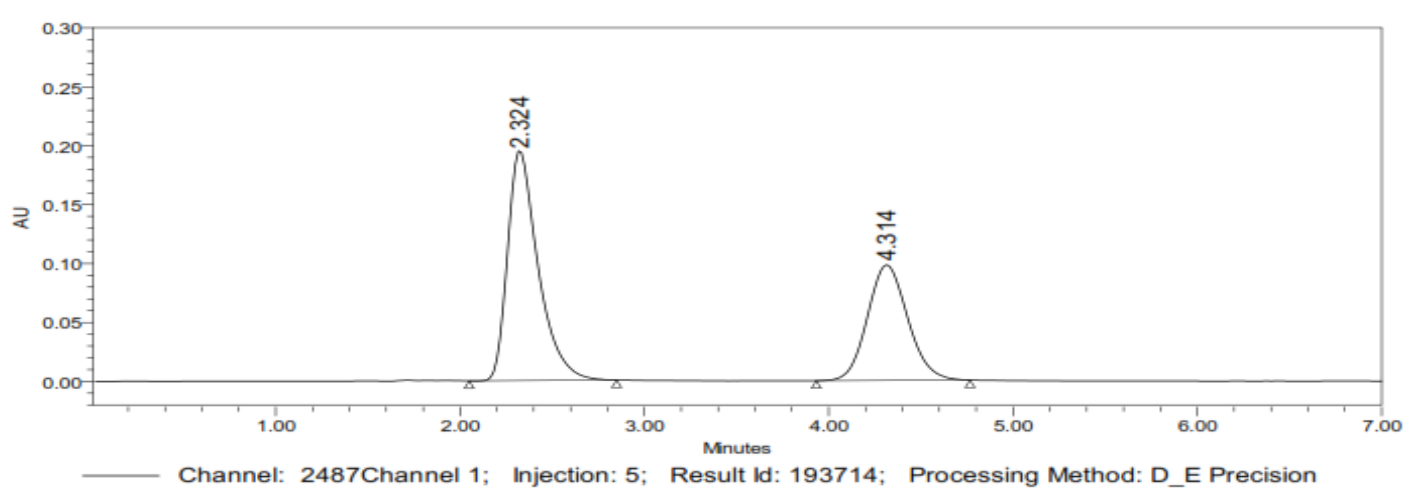

Fig. 7: Chromatogram for Precession

\section{Acceptance Criteria}

The $\%$ RSD for the area of five standard injections results should not be more than $2 \%$

The Method precision study was performed for the \%RSD of Cobicistat and Darunavir was found to be 0.3 and 0.3 (NMT 2). 
Table: 4. Data table of LOD

and LOQ for Cobicistat\& Darunavir

\begin{tabular}{|c|c|c|}
\hline Drug & LOD $(\mu \mathrm{g} / \mathrm{ml})$ & $\mathrm{LOQ}(\boldsymbol{\mu g} / \mathbf{m l}$ \\
\hline Cobicistat & 2.95 & 10.0 \\
\hline Darunavir & 3.04 & 9.87 \\
\hline
\end{tabular}

\section{CONCLUSION}

The retention times were found to be 2.399 mins and 3.907 mins. The \% purity of Cobicistat and Darunavir was found to be $100.7 \%$ and $101.4 \%$ respectively. The system suitability parameters for Cobicistat and Darunavir such as theoretical plates and tailing factor were found to be 1.3, 5117.5 and $1.4,3877.3$ the resolution was found to be 8.0. The analytical method was validated according to $\mathrm{ICH}$ guidelines $(\mathrm{ICH}$, Q2 (R1)). The linearity study for Cobicistat and Darunavir was found in concentration range of $1 \mu \mathrm{g}-5 \mu \mathrm{g}$ and $100 \mu \mathrm{g}-500 \mu \mathrm{g}$ and correlation coefficient ( $r 2$ ) was found to be 0.999 and 0.999 , \% mean recovery was found to be $100 \%$ and $100.5 \%$, \%RSD for repeatability was 0.2 and $0.4, \%$ RSD for intermediate precision was 0.5 and 0.1 respectively. The precision study was precise, robust, and repeatable. LOD value was 2.95 and 3.04 , and LOQ value was 9.87 and 10 respectively. Hence the suggested RPHPLC method can be used for routine analysis of Cobicistat and Darunavir in API and Pharmaceutical dosage form.

\section{REFERENCES}

1. Suneetha A. A Validated RP HPLC method for Simultaneous Estimation of Darunavir in Combined Dosage Form. International Journal of Pharmacy and Pharmaceutical Sciences. 2011;3(1).

2. Putchakayala Purnachandra Rao. Simple and Sensitive Analytical Method Development and Validation of Tenofovir disoproxyl fumarate, Cobicistat, Elvitegravir Bulk Drug by RP-HPLC. Der Pharma Chemica. 2011;3(6):494-499.

3. Nageswara Rao R. Simple and Sensitive Analytical Method Development and Validation Of cobicistat Bulk Drug by RPHPLC. Der Pharma Chemica. 2011;3(6):494-499.

4. Drugs and Cosmetics Act. 1940 and Rules, 1945, 2nd edition, Susmit publishers, Mumbai, India. 2000.

5. Indian Pharmacopoeia, Ministry of Health \& Family Welfare, Government of India, New Delhi. 1996.

6. Nagaraju P. Development and Validation of Reverse Phase HPLC Method for the Simultaneous Estimation of Lopinavir and Ritonavir in Pharmaceutical Dosage Forms. International Journal of Research in Pharmaceutical and Biomedical Sciences. 2001;28(1):192-197.

7. Ranjith singh. HPLC Method Development and Validation- an Overview. J Pharm Educ Res. 2013;4:2633.

8. USP 31/NF 26. United States Pharmacopoeia, 31st rev. and the National Formulary, 26 ed. United States Pharamcopoeial Convention. Rockville. 2008.

9. Snyder LR, Kirkland JJ and Joseph LG. Practical HPLC Method Development, Wiley Inter Science, New York, 2nd Ed. 1997;1-56.

10. ICH: Q2B, Analytical Validation Methodology. 1996. 